Provided for non-commercial research and education use. Not for reproduction, distribution or commercial use.

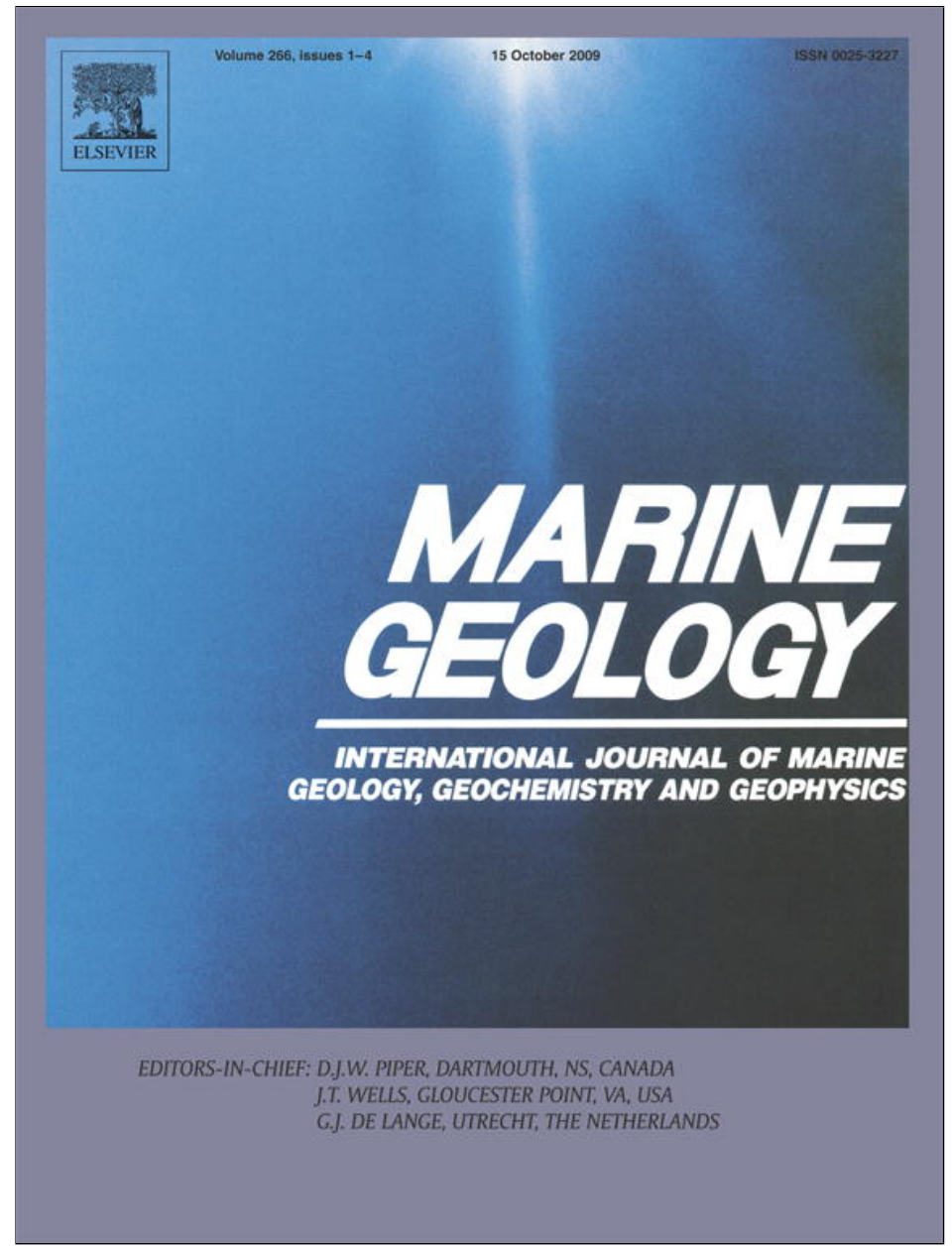

This article appeared in a journal published by Elsevier. The attached copy is furnished to the author for internal non-commercial research and education use, including for instruction at the authors institution and sharing with colleagues.

Other uses, including reproduction and distribution, or selling or licensing copies, or posting to personal, institutional or third party websites are prohibited.

In most cases authors are permitted to post their version of the article (e.g. in Word or Tex form) to their personal website or institutional repository. Authors requiring further information regarding Elsevier's archiving and manuscript policies are encouraged to visit:

http://www.elsevier.com/copyright 


\title{
Sedimentary deposits on the southern South African continental margin: Slumping versus non-deposition or erosion by oceanic currents?
}

\author{
Gabriele Uenzelmann-Neben ${ }^{\text {a,* }}$, Katrin Huhn ${ }^{\text {b }}$ \\ a Alfred-Wegener-Institut für Polar- und Meeresforschung, Am Alten Hafen 26, 27572 Bremerhaven, Germany \\ ${ }^{\mathrm{b}}$ MARUM, Center for Marine Environmental Sciences, University of Bremen, Leobener Str., 28359 Bremen, Germany
}

\section{A R T I C L E I N F O}

\section{Article history:}

Received 5 January 2009

Received in revised form 15 July 2009

Accepted 17 July 2009

Available online 3 August 2009

Communicated by D.J.W. Piper

\section{Keywords:}

reflection seismic data

South African continental margin

erosion

oceanic currents

Neogene

\begin{abstract}
A B S T R A C T
Seismic profiles extending from the southern South African shelf into the deep sea reveal a strong erosional activity, which affects large parts of the continental margin. Quaternary to Oligocene units and, in places, the complete sedimentary column appear to have been removed. Mass movements were previously considered as the origin of this erosion. However, structures indicating slumping can be identified in only a few places. The erosional activity is confined to specific water depths, which correlate well with the activity levels of water masses observed here. We thus suggest that the Agulhas Current, Antarctic Intermediate Water, North Atlantic Deep Water, and Antarctic Bottom Water have intensively shaped the sedimentary units over a long period. This indicates a stable circulation comparable to that at present day since the Neogene.
\end{abstract}

(C) 2009 Elsevier B.V. All rights reserved.

\section{Introduction}

The South African continental margin is characterized by deep basins filled with thick sedimentary rocks. It forms part of the South African gateway, where warm and cold-water masses originating in the Atlantic, the Indian and the Southern Oceans meet and mix. Heat is transferred between those oceans, which in turn maintains the global conveyor belt. The traces of this activity can be found in the sediment deposits offshore South Africa.

Up to now, seismic surveys have concentrated on the study of (a) the structural evolution of the margin (Martin and Hartnady, 1986; Ben Avraham et al., 1993, 1994, 1997; Martin, 2007; Parsiegla et al., 2008), (b) the Mesozoic units that document break up and post-break up (Dingle and Hendey, 1984; Broad et al., 2006), and (c) the Quaternary units of the continental margin because they bear traces of the glacial/interglacial cycles and thus rapid climate changes (Martin and Flemming, 1986; Martin and Flemming, 1988; Compton et al., 2002; Rau et al., 2002; Compton et al., 2004; Rau et al., 2006).

With this study, we will concentrate on the distribution of Neogene sedimentary rocks. Major plate tectonic events such as the opening of the Tasmanian gateway and the Drake Passage (both during the Paleogene) and the closure of the Central American Seaway (during the Neogene) had a strong effect on climate by modifying the oceanic circulation. The glaciations of Antarctica and the onset of the Antarctic Circumpolar

\footnotetext{
* Corresponding author. Tel.: +49 471 48311208; fax +49 47148311271.

E-mail address: Gabriele.Uenzelmann-Neben@awi.de (G. Uenzelmann-Neben).
}

Current have been suggested to result from those tectonic movements (Barker and Thomas, 2004; Scher and Martin, 2008). Hence, the Neogene units represent an archive of the modified circulation and climate. Study of the deep sea units has led to models for the development of climate and oceanic currents in the South African gateway (Dingle et al., 1987; Dingle and Camden-Smith, 1979; Niemi et al., 2000; Schlüter and Uenzelmann-Neben, 2008), but little is known about the Neogene units on the South African continental margin. Major open questions in this context are: what effect did the modifications in circulation and climate have on the deposits on the continental shelf and slope? Can we identify traces of the exchange of water masses between the Indian and Atlantic Oceans that might indicate onset of a modern type circulation in the Neogene? To gain a deeper insight into the evolution of both currents and climate during this period, seismic reflection data from the South African continental margin were analyzed. The results are presented here.

\section{Geological background}

The opening of the South Atlantic began about 130 Ma when the Falkland Plateau started to slide westwards along the Agulhas-Falkland Fracture Zone (AFFZ). Initial spreading led to the formation of the Natal Valley (Fig. 1) (Ben Avraham et al., 1993, 1997) followed by the creation of the Transkei Basin during the Cretaceous magnetic quiet interval (Fullerton et al., 1989), with spreading being complete by $90 \mathrm{Ma}$ (Martin and Hartnady, 1986; Ben Avraham et al., 1993). The Agulhas Plateau, a structure just west of the Transkei Basin, is the result of the interaction of several spreading centres and the Bouvet Hotspot at 100-80 Ma 
66 G. Uenzelmann-Neben, K. Huhn / Marine Geology 266 (2009) 65-79

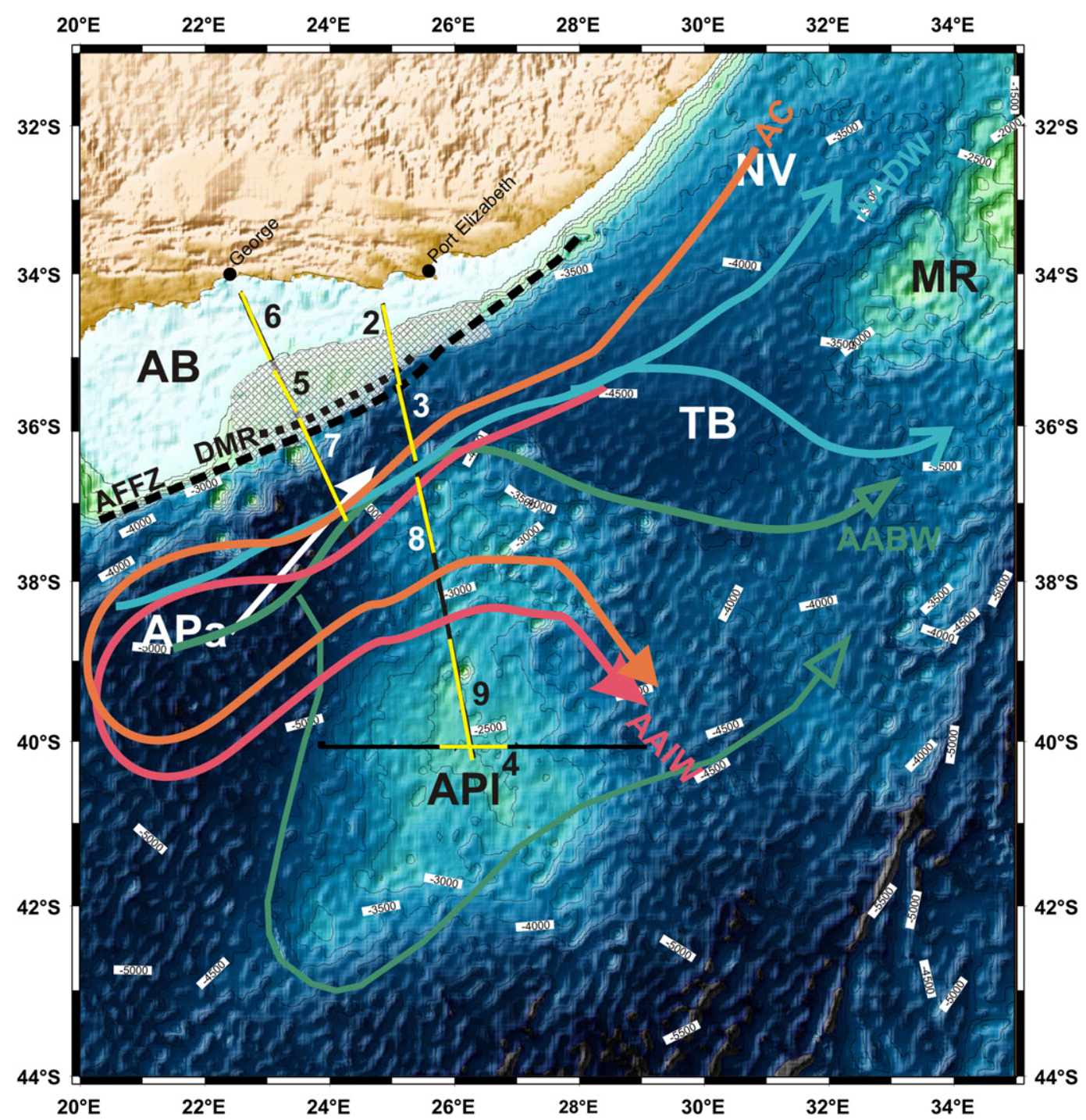

Fig. 1. Bathymetric map (Sandwell and Smith, 1997) of the southern South African continental margin showing the location of the seismic profiles as black lines. The yellow parts of the seismic lines are shown in Figs. 2-9. The coloured arrows show the schematic paths of the Agulhas Current AC, Antarctic Intermediate Water AAIW, North Atlantic Deep Water NADW, and Antarctic Bottom Water AABW. The shaded area shows the approximate location of the Agulhas Slump (Dingle, 1977). AB=Agulhas Bank, AFFZ = Agulhas-Falkland Fracture Zone, $\mathrm{APa}=$ Agulhas Passage, $\mathrm{APl}=$ Agulhas Plateau, $\mathrm{DMR}=$ Diaz Marginal Ridge, $\mathrm{MR}=$ Mozambique Ridge, $\mathrm{NV}=\mathrm{Natal}$ Valley, $\mathrm{TB}=\mathrm{Transkei}$ Basin.

(Uenzelmann-Neben et al., 1999; Gohl and Uenzelmann-Neben, 2001; Parsiegla et al., 2008) and has represented an obstacle to the oceanic circulation ever since.

Investigations by Barrett (1977), Tucholke and Carpenter (1977), and Tucholke and Embley (1984) have shown that the sedimentary development in the deep sea south of South Africa started in Maastrichtian times. There, only little terrigenous sediment input was observed. The sedimentary units are characterized by a number of hiatuses, which are due to erosion and non-deposition. The situation is different on the shelf, where a complex set of basins has been identified, which are separated from the AFFZ by the Diaz Marginal Ridge (DMR) (Fig. 1), a ridge composed of meta-sediments (Parsiegla et al., 2007). Those basins are filled with sedimentary rocks of Jurassic to Tertiary age of up to $8 \mathrm{~km}$ thickness (Fig. 1) (Ben Avraham et al., 1997; Broad et al., 2006). Only few details are known about the Tertiary units. Most studies have concentrated on the effect that glacial/interglacial cycles have had on the sedimentary environment and on Holocene deposits (Martin and Flemming, 1986, 1988; Rau et al., 2002, 2006; Diz et al., 2007; Molyneux et al., 2007). Modern river input to the south coast comprises about $18 \%$ of the total terrigenous sediment material, with Pleistocene sediments on most of the Agulhas Bank consisting of relict quartz and benthic carbonate sands (Dingle et al., 1987).
A major submarine slump has been reported to have affected the south-eastern side of the Agulhas Bank ( $22^{\circ} \mathrm{E}$ to $\left.27-30^{\circ} \mathrm{E}\right)$ in Pliocene or younger times (Fig. 1) (Dingle, 1977). According to Dingle's (1977) studies, this Agulhas Slump is $750 \mathrm{~km}$ long and $106 \mathrm{~km}$ wide, with a volume of over $20,000 \mathrm{~km}^{3}$. It is a composite feature consisting of proximal and distal allochthonous sediment masses separated by a large glide plane scar (Dingle, 1977). The head region is located in water depths of 190-700 m, while the toe region extends into the deep sea (Dingle, 1977). Basement ridges have dammed the slump in the western part, whereas in the east, allochthonous material has spread into the Transkei Basin.

\section{Oceanographic setting}

After the final separation of Antarctica from its surrounding continents in Oligocene times (Lawver and Gahagan, 1998; Eagles et al., 2006), a circumpolar current developed, leading to the glaciations of Antarctica and the production of Antarctic Bottom Water (AABW) (Mackensen and Ehrmann, 1992; Zachos et al., 2001). Today, AABW flows northwards and then eastwards (a) through the Agulhas Passage, and (b) across the southern margin of the Agulhas Plateau into the Transkei Basin (Tucholke and Embley, 1984). This 
water mass is transported further into the Mozambique Basin (Read and Pollard, 1999).

North Atlantic Deep water NADW is observed to flow from the Atlantic Ocean through the Agulhas Passage into the Transkei Basin and onwards into (a) the Natal Valley, and (b) the Indian Ocean (Van Aken et al., 2004) (Fig. 1).

Antarctic Intermediate Water AAIW originates from surface water around Antarctica. From there it flows northwards into the Indian Ocean where it extends to water depths of up $1200 \mathrm{~m}$. After recirculation through the Indian Ocean, AAIW flows westwards along the Agulhas Bank (You et al., 2003). At the south-western tip of South Africa, AAIW turns eastwards again in a retroflection and flows across the Agulhas Plateau into the Indian Ocean (Lutjeharms, 1996) (Fig. 1)

The Agulhas Current is the western boundary current of the Indian Ocean and extends to water depths greater than $2000 \mathrm{~m}$ (Winter and Martin, 1990; Lutjeharms, 1996; De Ruijter et al., 1999). The Agulhas Current is guided south-westwards by the steep continental slope of the Agulhas Bank. Southwest of South Africa, the Agulhas Current turns abruptly eastward in a tight retroflection loop and becomes known as the Agulhas Return Current (ARC). This current flows eastwards to the Agulhas Plateau where it forms a major northward loop around the plateau (Camden-Smith et al., 1981; Lutjeharms, 1996; De Ruijter et al., 1999) (Fig. 1).

\section{Data acquisition}

In 2005, the Alfred-Wegener Institute for Polar- and Marine Research gathered two seismic reflection lines extending from the continental shelf of South Africa into the deep sea using the German research vessel SONNE (Fig. 1). A cluster of eight G-guns was used as the seismic source (total volume $98 \mathrm{l}$ ). The guns were fired once per minute (corresponding to a shot spacing of approximately $150 \mathrm{~m}$ ), producing signals with frequencies of up to $150 \mathrm{~Hz}$. Data were received using a high-resolution seismic data acquisition system (SERCEL SEALC), consisting of both onboard and in-sea equipment. The total active streamer length was $2250 \mathrm{~m}$, consisting of 180 channels, and additionally a lead-in cable length of $150 \mathrm{~m}$. Navigation data were provided by GPS (Global Positioning System). Having used a temporal sampling rate of $2 \mathrm{~ms}$ during recording, the theoretical sampling rate in depth (specifying the vertical resolution) is $8 \mathrm{~m}$, using a velocity of $2000 \mathrm{~m} / \mathrm{s}$ for the conversion. Processing of the seismic reflection data comprised geometry definition using the ship's navigation data, and CDP-sorting with a CDP spacing of $50 \mathrm{~m}$. A stretch-mute was applied to suppress the direct wave, which disturbed the primaries on the shelf, and a Radon Transform filtering process was used to suppress the multiples. A precise velocity analysis (every $50 \mathrm{CDP}$ ) was carried out and used for spherical divergence and normal moveout correction. After stacking, migration was carried out both in time and depth domain (Omega-X migration, Yilmaz, 2001). The stacking velocities, which were converted into interval velocities using Dix's formula, were used to set up the velocity field used for the migration process and the embedded conversion from time to depth. Filtering or gain modules were applied to the data only for on-screen analysis.

Coevally, sediment echosounder data were continuously recorded utilizing a PARASOUND system, which is permanently installed on RV SONNE with primary signals of $18 \mathrm{kHz}$ and $22 \mathrm{kHz}$ and a secondary frequency of $4 \mathrm{kHz}$. A burst of pulses is emitted at $400 \mathrm{~ms}$ intervals until the first echo returns. On average, one seismogram is recorded about every second providing a spatial resolution on the order of a few meters on seismic profiles at a speed of the vessel of $5.0 \mathrm{kn}$. Afterwards, the echogram sections were processed e.g., filtered with a wide band pass filter and normalized to a constant value, using the software package SENT.

\section{Seismostratigraphic model}

Three different seismostratigraphic models have been applied to our data because the seismic profiles cross three different geomorphological/geological units: (a) the continental shelf and slope, (b) the deep sea, in this case the Agulhas Passage, and (c) the Agulhas Plateau.

For geomorphological unit (a) - the continental shelf, Broad et al. (2006) provide a seismostratigraphic model. Unfortunately, they concentrated on Mesozoic unconformities in the deeper basins. The youngest unconformity discussed is 22At1 with an age of $67 \mathrm{Ma}$ corresponding to the Cretaceous-Tertiary boundary (Broad et al., 2006). For reasons of consistency, unconformity $22 \mathrm{At} 1$ here is referred to as reflector $\mathrm{K}-\mathrm{T}$ (Table 1; Fig. 2). Intra-Tertiary reflectors are not

Table 1

Seismostratigraphic models for the shelf, slope, Agulhas Passage, and Agulhas Plateau as used in this paper

\begin{tabular}{|c|c|c|c|}
\hline \multicolumn{4}{|c|}{ Shelf, slope, Agulhas Passage } \\
\hline Reflector name & Reflector age & Reflector origin (correlated with reflector of Agulhas Plateau) & Stratigraphic model \\
\hline & & Basement & Broad et al. (2006) \\
\hline $\mathrm{M}_{\mathrm{c}}$ & Intra-Cretaceous & & \\
\hline $\mathrm{K}-\mathrm{T}$ & $\begin{array}{l}\text { Cretaceous-Tertiary boundary } \\
(67 \mathrm{Ma})\end{array}$ & 22At1 & Broad et al. (2006) \\
\hline $\mathrm{O}$ & Eocene/Oligocene & (LO) & Niemi et al. (2000); Schlüter and Uenzelmann-Neben (2007) \\
\hline M & Middle Miocene & Mid-Miocene cooling affected oceanic currents (MM) & Niemi et al. (2000); Schlüter and Uenzelmann-Neben (2007) \\
\hline $\mathrm{P}$ & Early Pliocene & closure of CAS led to modifications in oceanic currents (LP) & Niemi et al. (2000); Schlüter and Uenzelmann-Neben (2007) \\
\hline \multicolumn{4}{|l|}{ Agulhas Plateau } \\
\hline Reflector name & Reflector age & $\begin{array}{l}\text { Reflector origin (correlated with reflector of shelf, slope, } \\
\text { and Agulhas Passage) }\end{array}$ & Stratigraphic model \\
\hline B & & Basement & $\begin{array}{l}\text { Tucholke and Carpenter (1977); Tucholke and Embley (1984); } \\
\text { Uenzelmann-Neben (2001) }\end{array}$ \\
\hline Ma & Maastrichtian & & $\begin{array}{l}\text { Tucholke and Carpenter (1977); Tucholke and Embley (1984); } \\
\text { Uenzelmann-Neben (2001) }\end{array}$ \\
\hline LE & Paleocene/Eocene boundary & Sealevel highstand and low sedimentation rate & $\begin{array}{l}\text { Tucholke and Carpenter (1977); Tucholke and Embley (1984); } \\
\text { Uenzelmann-Neben (2001) }\end{array}$ \\
\hline LO & Early/Middle Oligocene & Production and spreading of ACC $(0)$ & $\begin{array}{l}\text { Tucholke and Carpenter (1977); Tucholke and Embley (1984); } \\
\text { Uenzelmann-Neben (2001) }\end{array}$ \\
\hline MM & Middle Miocene & Erosion/re-deposition due to AABW (M) & $\begin{array}{l}\text { Tucholke and Carpenter (1977); Tucholke and Embley (1984); } \\
\text { Uenzelmann-Neben (2001) }\end{array}$ \\
\hline $\mathrm{LP}$ & Late Miocene/Early Pliocene & Erosion/re-deposition by CDW within ACC (P) & $\begin{array}{l}\text { Tucholke and Carpenter (1977); Tucholke and Embley (1984); } \\
\text { Uenzelmann-Neben (2001) }\end{array}$ \\
\hline
\end{tabular}

ACC = Antarctic Circumpolar Current, CAS = Central American Seaway, CDW = Circumpolar Deepwater 


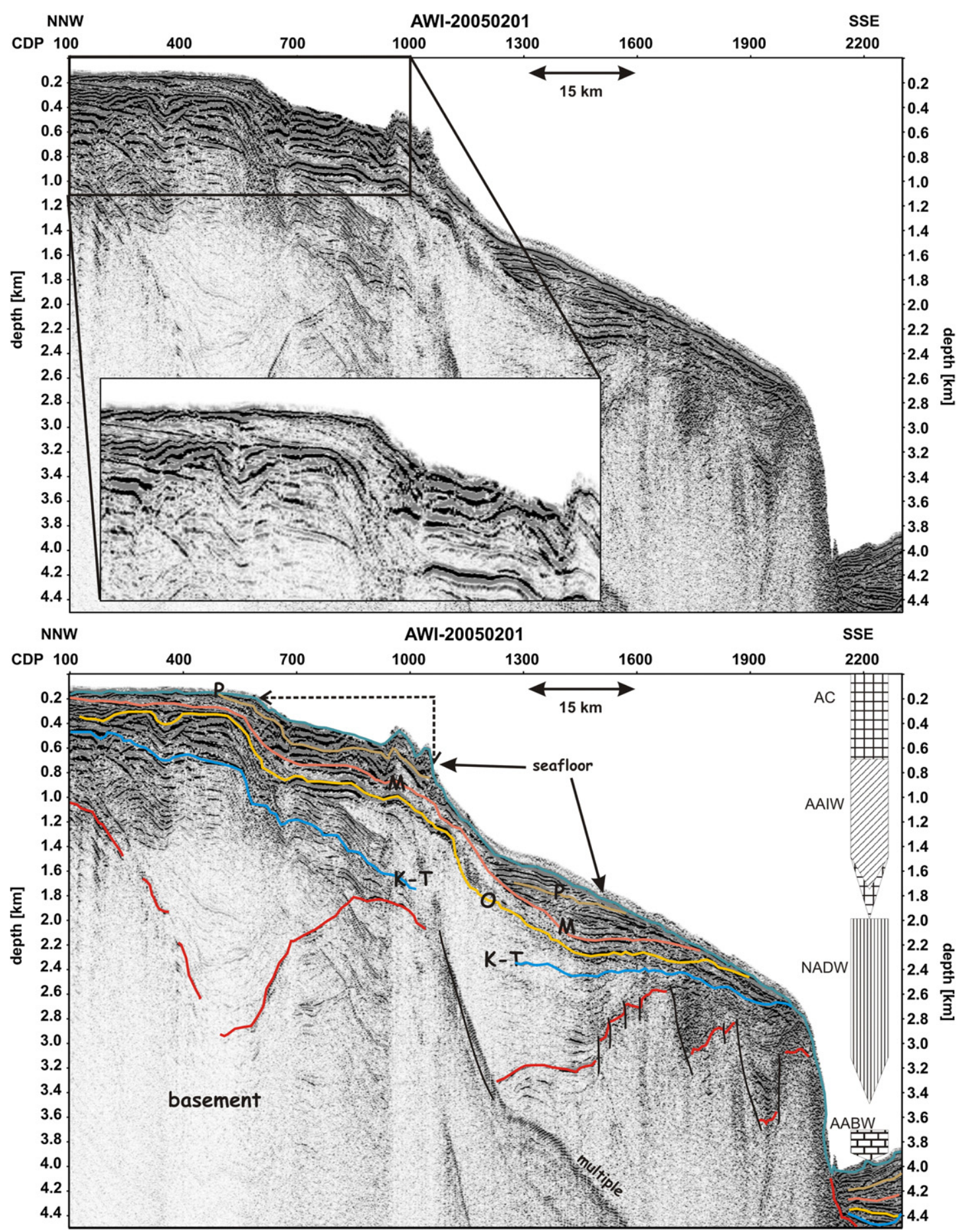

Fig. 2. Profile AWI-20050201 showing the shelf and continental slope into the Agulhas Passage. For location see Fig. 1. The dashed line shows the extent of the proximal part of the Agulhas Slump according to Dingle (1977). The hatched blocks show the activity levels of the Agulhas Current AC, Antarctic Intermediate Water AAIW, North Atlantic Deep Water $\mathrm{NADW}$, and Antarctic Bottom Water AABW. $\mathrm{K}-\mathrm{T}=$ Cretaceous-Tertiary boundary, $\mathrm{M}=$ Miocene, $\mathrm{O}=$ Eocene/Oligocene, $\mathrm{P}=\mathrm{Pliocene}$.

discussed by Broad et al. (2006) and, based on their reflection characteristics, have hence been interpreted (reflectors $\mathrm{O}, \mathrm{M}$, and $\mathrm{P}$ ) using the seismostratigraphic model of Niemi et al. (2000), which is applied to the part of the seismic data crossing the Agulhas Passage.

Six sedimentary units can be defined for the Agulhas Passagegeomorphological unit (b). The dating of those units and the top reflectors is based on Niemi et al. (2000). We distinguish between sedimentary units of Cretaceous, Late Eocene-Oligocene, OligoceneMiddle Miocene, Middle Miocene-Early Pliocene, and Early PlioceneHolocene age (Table 1; Fig. 3). The details of the correlation of our seismic data with the seismostratigraphic model defined by Niemi et al. (2000) can be found in Schlüter and Uenzelmann-Neben (2007).

Based on information put forward by Tucholke and Carpenter (1977) and Tucholke and Embley (1984), Uenzelmann-Neben (2001) developed a seismostratigraphic model for the third region - the Agulhas Plateau. The six sedimentary units observed there range from Late Cretaceous, Late Cretaceous-Paleocene, Eocene-Early Oligocene, Early/Middle OligoceneMiddle Miocene, Middle-Late Miocene, and Late Miocene/Early PlioceneHolocene in age (Table 1; Fig. 4). For details on the dating of the seismic reflectors we refer to Uenzelmann-Neben (2001). 
G. Uenzelmann-Neben, K. Huhn / Marine Geology 266 (2009) 65-79

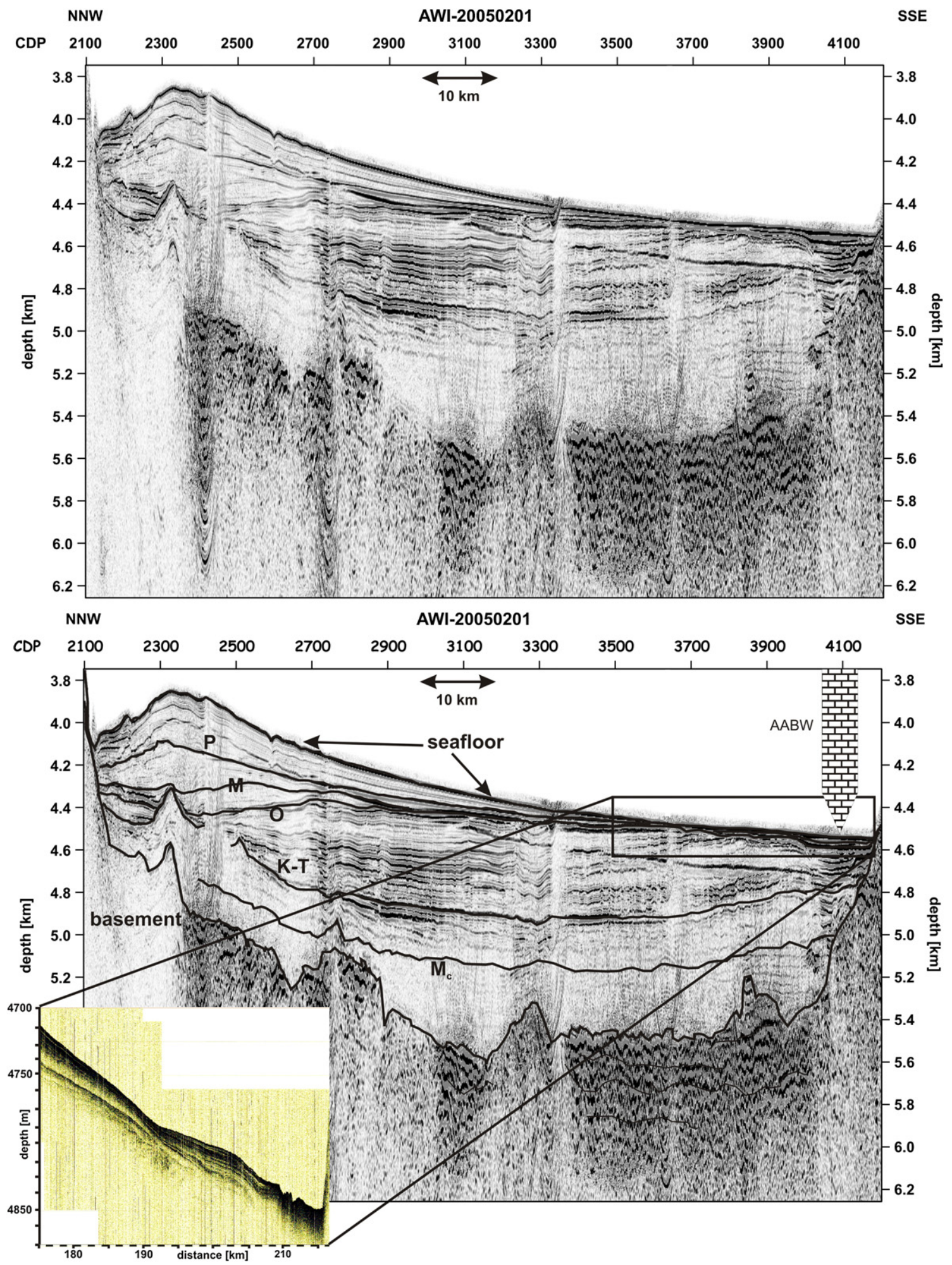

Fig. 3. Seismic reflection profile AWI-20050201 (for location see Fig. 1). The blown-up part is a part of the sediment echosounding recordings. Note the different scale. The dashed block shows the activity level of Antarctic Bottom Water AABW. $\mathrm{K}-\mathrm{T}=$ Cretaceous-Tertiary boundary, $\mathrm{M}=$ Miocene, $\mathrm{M}_{\mathrm{c}}=$ intra-Cretaceous, $\mathrm{O}=$ Eocene/Oligocene, $\mathrm{P}=\mathrm{Pliocene}$.

A direct correlation of the reflectors identified on the shelf, slope, and the Agulhas Passage with those identified on the Agulhas Plateau is not possible because the steep northern flank of the Agulhas Plateau as well as the sparse sediment cover of the northern plateau prevent this. A correlation is thus carried out based on the interpreted reflector origin and age. We thus correlate reflector $O$ of the shelf, slope, and the Agulhas Passage with reflector LO of the plateau, reflector M with reflector MM, and reflector P with reflector LP (Table 1).

\section{Results}

Following the application of this stratigraphic model, structures in pre-Cretaceous sedimentary layers can be identified. The basement, which, on the basis of seismic velocities, has been interpreted as metasediments beneath the continental shelf and slope and as crystalline basement beneath the continental rise and the Agulhas Passage (Parsiegla et al., 2007, 2008), can be found in depths of more than 

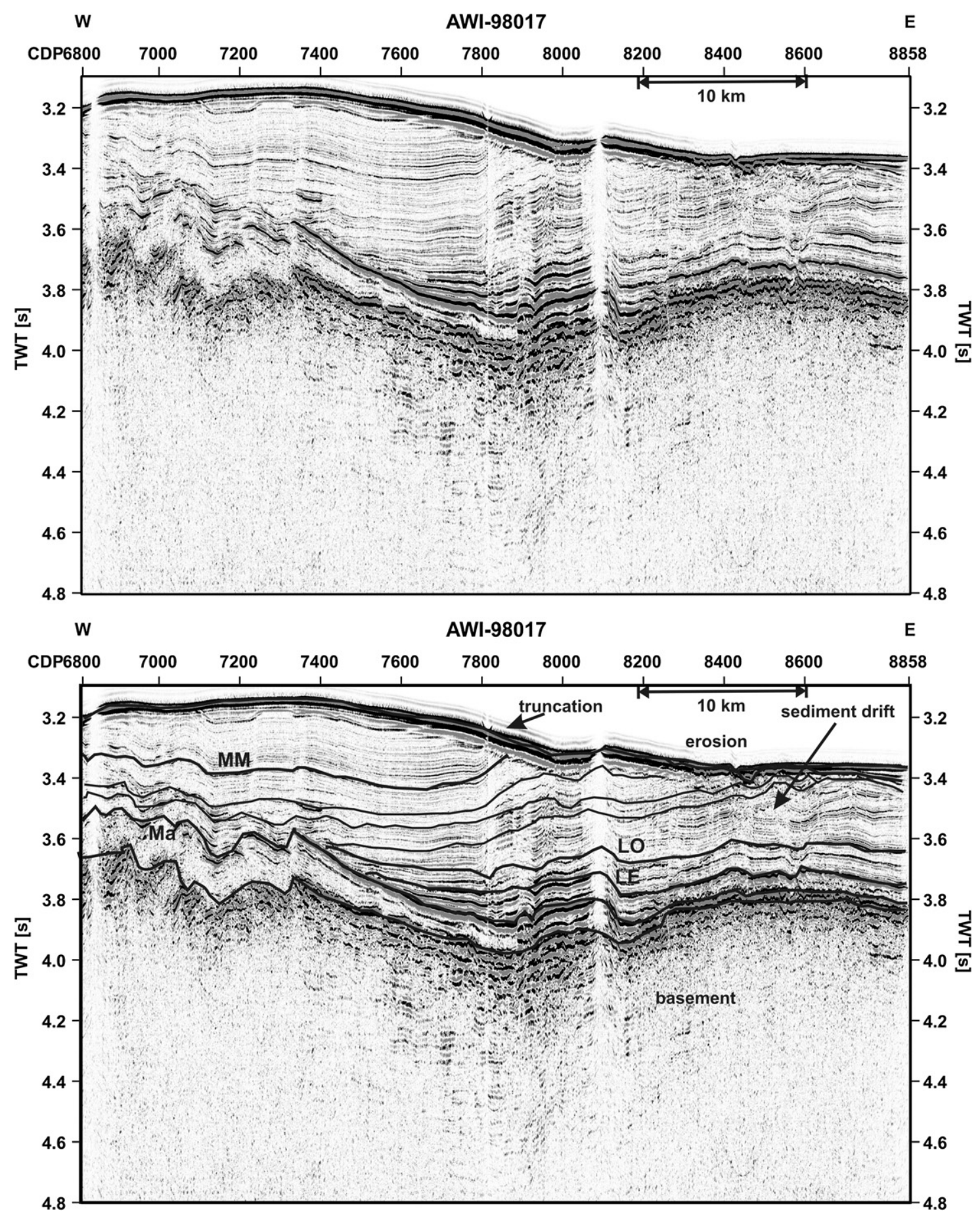

Fig. 4. Profile AWI-98017 across the central southern Agulhas Plateau showing erosion of the sedimentary units. For location see Fig. 1. Modified from Uenzelmann-Neben et al. (2007) . $\mathrm{LE}=$ Paleocene/Eocene boundary, $\mathrm{LO}=$ Early/Middle Oligocene, $\mathrm{Ma}=$ Maastrichtian, $\mathrm{MM}=$ Middle Miocene.

$2.5 \mathrm{~km}$ (Fig. 2). The basins of the Agulhas Bank are imaged very well in both profiles (Figs. 2 and 5).

\subsection{Continental shelf and slope}

The oldest Tertiary unit below reflector $\mathrm{O}$ has a thickness of up to $600 \mathrm{~m}$ on the continental shelf. Channels cut through this unit down into reflector K-T (Fig. 6, CDPs 550-1450). The top reflector of this unit, reflector $\mathrm{O}$, shows a good continuity and can be traced easily. The unit thins towards the Diaz Ridge. There, it wedges out against reflector K-T (Figs. 2, CDPs 1400-2050, and 5, CDPs 3400-3900).

Unit O-M is up to $400 \mathrm{~m}$ thick with a mean thickness of $200 \mathrm{~m}$ (Figs. 2, 5, and 6). The unit thins towards the Diaz Ridge (Figs. 2 and 5). It is affected by the cutting of channels (Fig. 6, CDPs 1500-2000). Reflector M, which forms the top of this unit, is a continuous reflection of moderate to high amplitude. On the shelf, unit O-M shows toplap

Fig. 5. Seismic reflection profile AWI-20050101 (for location see Fig. 1). Note erosional patches between CDPs 2600-3200 and 3600-4100. The blown-up parts are sediment echosounding recordings. The dashed line shows the extent of the proximal part of the Agulhas Slump according to Dingle (1977). The hatched blocks show the activity levels of the Agulhas Current AC, Antarctic Intermediate Water AAIW, and North Atlantic Deep Water NADW. K-T $=$ Cretaceous-Tertiary boundary, $\mathrm{M}=$ Miocene, $\mathrm{O}=$ Eocene/Oligocene, $\mathrm{P}=\mathrm{Pliocene}, ?=$ unknown age of reflector. 
G. Uenzelmann-Neben, K. Huhn / Marine Geology 266 (2009) 65-79

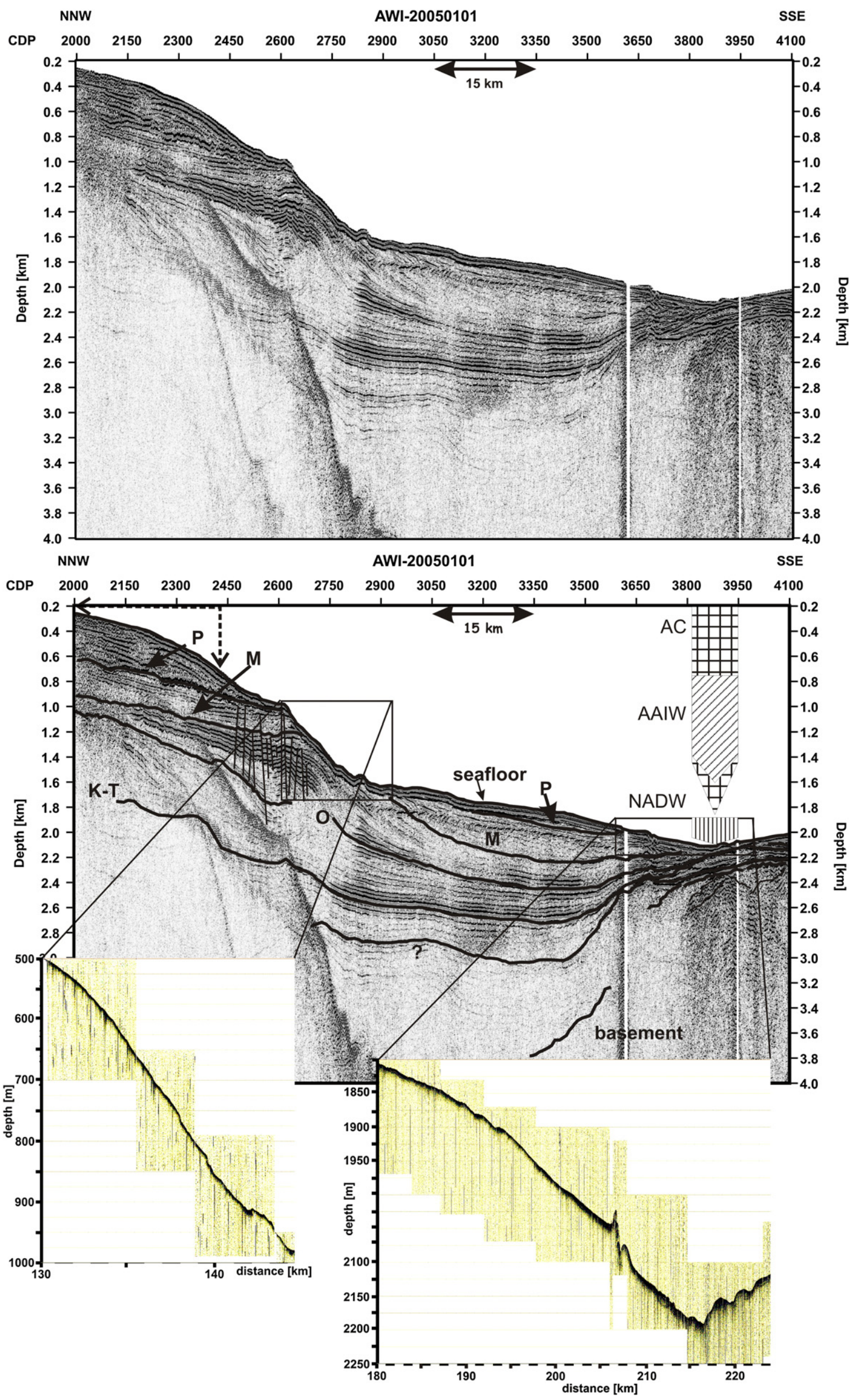




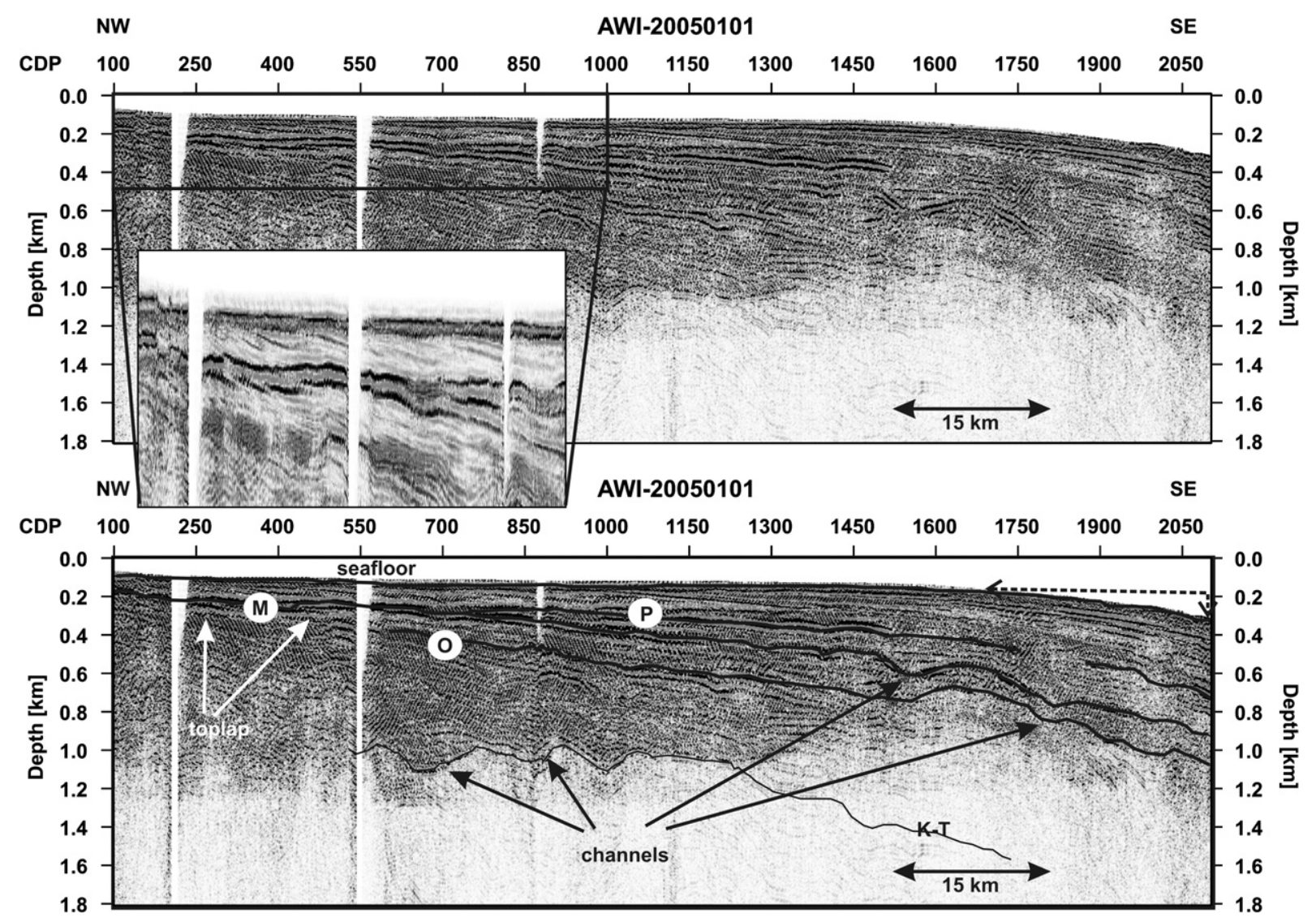

Fig. 6. Profile AWI-20050101 showing erosional and non-depositional structures on the shelf (toplap, channels). For location see Fig. 1. The dashed line shows the extent of the proximal part of the Agulhas Slump according to Dingle (1977). K-T = Cretaceous- Tertiary boundary, $\mathrm{M}=$ Miocene, $\mathrm{O}=$ Eocene/Oligocene, $\mathrm{P}=\mathrm{Pliocene}$.

and/or erosional truncation indicating non-deposition and/or erosion (Fig. 6, CDPs 100-700). Both toplap and erosional truncation are reflector terminations that represent sediment bypass or erosion. Erosional truncation is more extreme than toplap implying physical development of erosional relief (Emery and Myers, 1996).

Unit M-P shows a maximum thickness of $300 \mathrm{~m}$. This unit thins landwards and then wedges out against reflector M (Fig. 6, CDPs 7001900). It also rises and thins due to erosion towards the Diaz Ridge (Fig. 5, CDPs 3500-3900). The youngest unit P-recent is up to $400 \mathrm{~m}$ thick on the shelf and shows only about $150 \mathrm{~m}$ in thickness on the slope.

In general, all sedimentary units are strongly affected by erosion. We observe erosion into unit O-M on line AWI-20050101 between CDPs 2500 and 3200 (Fig. 5) and on line AWI-20050201 seaward of CDP 1780 (Fig. 2). Erosion into unit M-P can be found on line AWI-20050101 between CDPs 4580 and 4680 (Fig. 7) and on line AWI-20050201 between CDPs 1050 and 1250 as well as from CDPs 1450 to 1780 (Fig. 2). Nearly the complete Tertiary sedimentary unit has been removed on line AWI-20050101 between CDPs 3500 and 4150 (Figs. 5 and 7), while we observe erosion down to basement between CDPs 5500 and 5800 (Fig. 7). Between the erosional patches on the slope, the sedimentary units form a kind of lenticular structure, where the sedimentary column appears to be complete (Figs. 2, CDPs 1200-1600, and 5, CDPs 3200-3650).

Sediment echosounding data show a very low penetration of less than $20 \mathrm{~m}$ (Fig. 5) indicative of hard and only thin soft sediments. This implies that the erosion already observed in the seismic data is a recent and ongoing process.

\subsection{Continental rise and Agulhas Passage}

On the continental rise, the sedimentary units are disturbed by faults, which extend from the basement to the seafloor (Fig. 7, CDPs 4450-5500). Here, the AFFZ is located, and those faults are most probably related to tectonic activity at the AFFZ as the result of a proposed reactivation (Parsiegla et al., 2007).

Very thin sedimentary layers characterize the western Agulhas Passage. In places (Fig. 7, CDPS 5600-5950 and 6800-7100), the basement is covered by only a thin veneer of sediments, which is below the resolution of our seismic data $(<8 \mathrm{~m})$. Two sediment deposits with a thickness of up to $300 \mathrm{~m}$ can be observed (Fig. 7, CDPs 5800-6300 and 7100-7800). The sediment echosounding data here show a penetration of up to $75 \mathrm{~m}$ thus indicating softer sediments for the upper part of the deposits, which comprise the Cenozoic sedimentary units.

In contrast to this sparse sedimentary cover, the central part of the Agulhas Passage shows up to $1300 \mathrm{~m}$ thick sedimentary layers, which form sediment drifts. A moat can be observed at the foot of the rise (Fig. 3, CDPs 2100-2200). Here, we find the northern, steep flank of the youngest sediment drift, which comprises the sedimentary units $\mathrm{O}-\mathrm{M}, \mathrm{M}-\mathrm{P}$ and P-recent. Erosion can be observed at this location. Below this sediment drift we observe a plastered drift in K-T-O sedimentary layers, which was later modified into an elongate drift during the Late Oligocene (Uenzelmann-Neben et al., 2007). The older drift also shows a steeper flank in the north, which is separated from the continental rise by a moat. The southern part of the Agulhas Passage is affected by thinning of the sedimentary layers as well as erosion. (Fig. 3, CDPs 2600-4200). Sediment echosounding data show clearly thinning as well as wedge-out and an erosional moat at the northern flank of the Agulhas Plateau, and hence support this interpretation (Fig. 3).

\subsection{Agulhas Plateau}

The Agulhas Plateau generally is characterized by basement highs. From those highs, inclined reflections emerge in all directions 


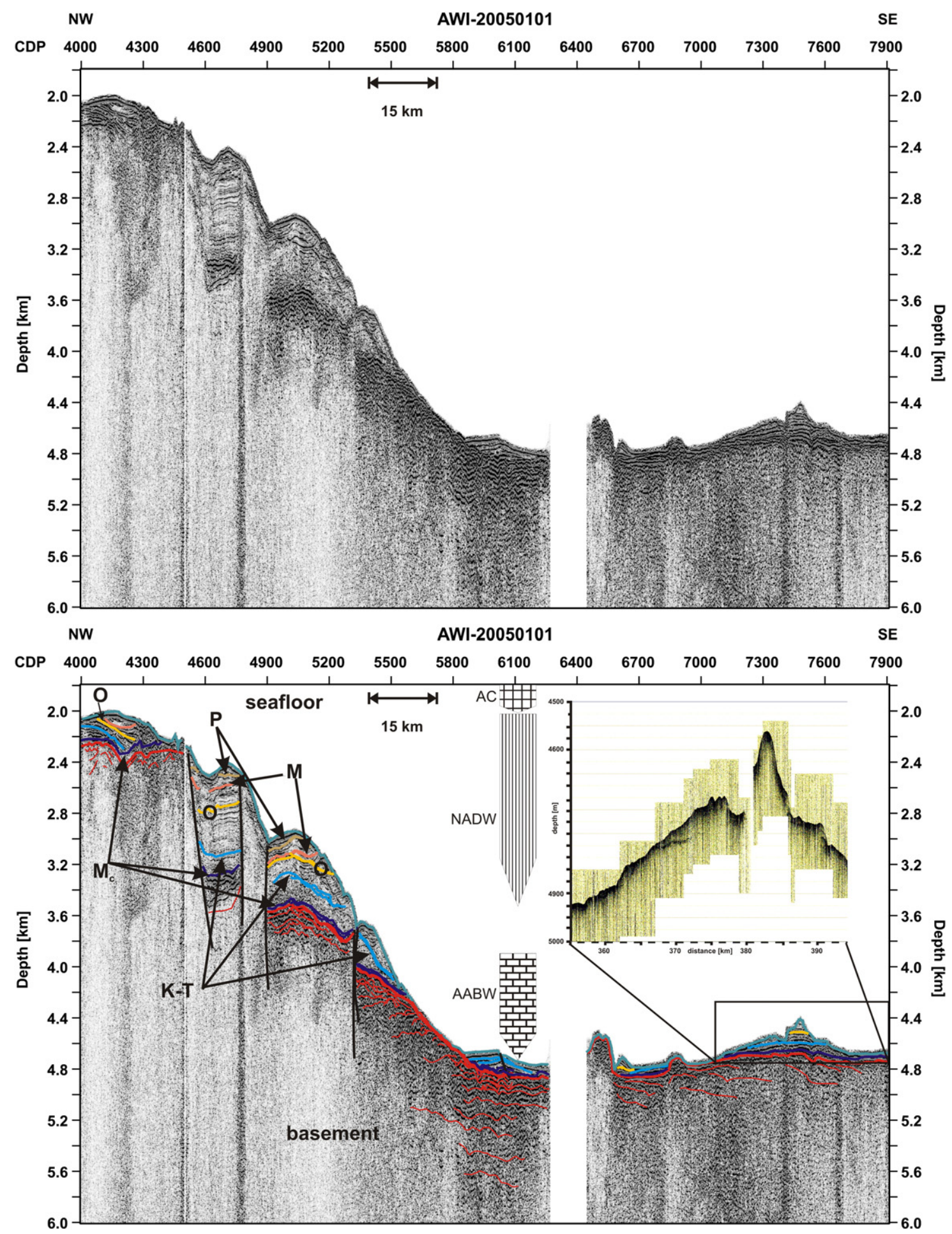

Fig. 7. Profile AWI-20050101 showing the continental rise and the Agulhas Passage (for location see Fig. 1). Note the different scale in the sediment echosounding data displayed in the blown-up part. The hatched blocks show the activity levels of the Agulhas Current AC, North Atlantic Deep Water NADW, and Antarctic Bottom Water AABW. K-T = CretaceousTertiary boundary, $\mathrm{M}=$ Miocene, $\mathrm{M}_{\mathrm{c}}=$ intra-Cretaceous, $\mathrm{O}=$ Eocene/Oligocene, $\mathrm{P}=$ Pliocene.

(Uenzelmann-Neben et al., 1999). Only thin sedimentary layers cover the basement. A number of faults and steep flanks indicate tectonic activity (Fig. 8, CDPs 4400, 4700, 5200, and 7300-7480). Sedimentary rocks are concentrated in pocket-like structures between the basement highs. Assigning an age to the sedimentary layers within those pockets is difficult. This is easier on the southern Agulhas Plateau, where the sedimentary units are generally thicker and more continuous (Figs. 4, and 9). Here, the seismic data have been tied into the stratigraphic model as defined by Tucholke and Carpenter (1977), Tucholke and Embley (1984), and Uenzelmann-Neben (2001).

Sedimentary layers of Miocene to recent age are very thin to absent on the plateau. The sedimentary units are strongly affected by the formation of sediment drifts and erosion. Erosion can be observed into the Oligocene layers (Figs. 8, CDPs 6050-6900, 7550-7800, and 9, CDPs 11200-13200). Sediment echosounding data here show a rough surface and a penetration of only $20 \mathrm{~m}$. This indicates hard material 

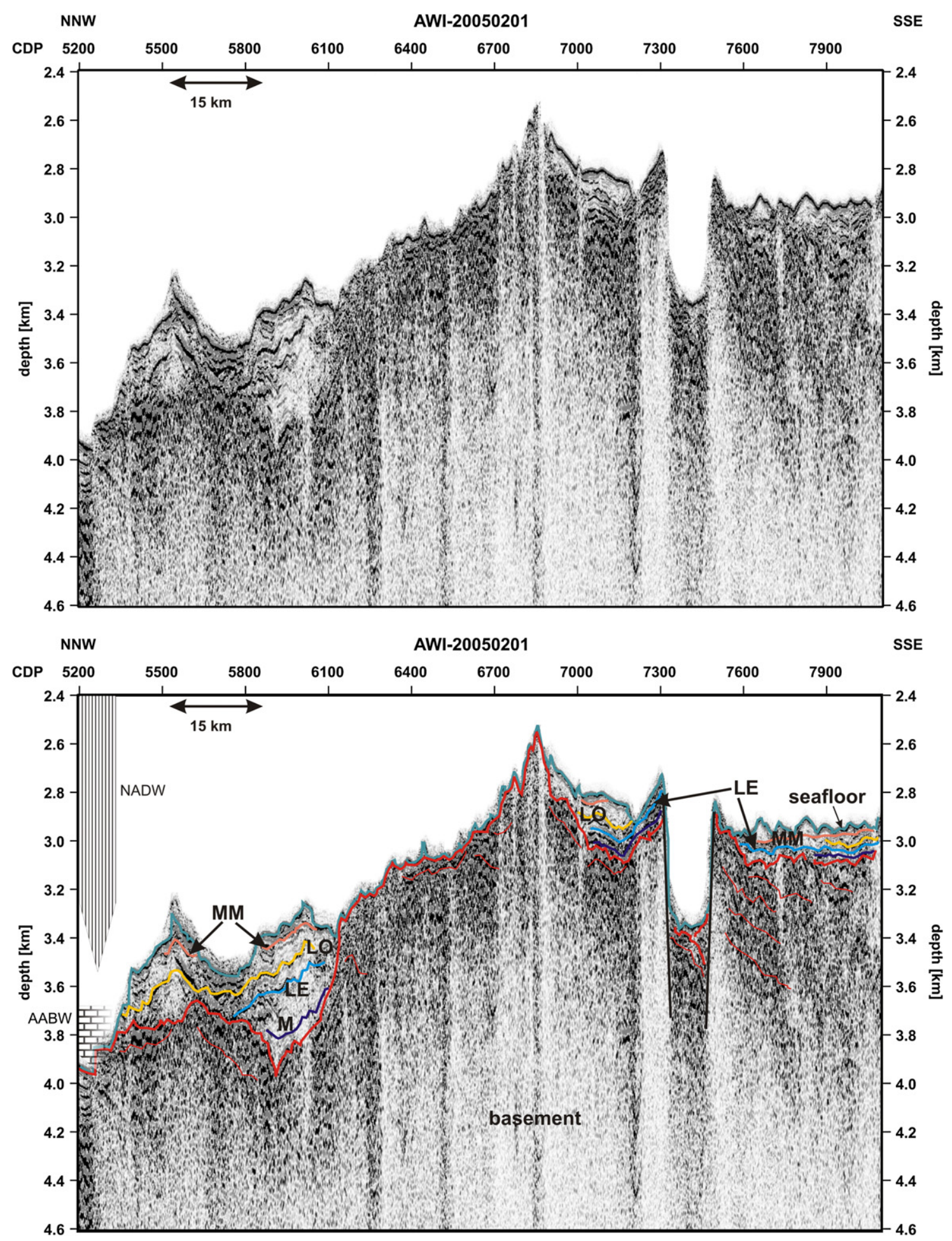

Fig. 8. Profile AWI-20050201 showing the northern Agulhas Plateau (for location see Fig. 1). The hatched blocks show the activity levels of North Atlantic Deep Water NADW, and Antarctic Bottom Water AABW. LE = Paleocene/Eocene boundary, LO=Early/Middle Oligocene, $\mathrm{LP}=$ Late Miocene/Early Pliocene, Ma $=$ Maastrichtian, MM $=$ Middle Miocene.

pointing towards a much reduced deposition of Quaternary sediments and/or ongoing erosion. Large areas of the northern Agulhas Plateau appear to be void of sedimentary units (Figs. 8, CDPs 6150-6900, 7300-7500, and 9, CDPs 10900-11200). Here, the thickness of the sedimentary column is less than $75 \mathrm{~m}$.

\section{Discussion}

The southern continental shelf of South Africa shows prograding units, which strongly thin shoreward. Toplap and/or erosional truncation indicate non-deposition and/or erosion of the layers. It is not possible to strictly distinguish between those two processes because toplap as a reflector termination also points towards erosion (Emery and Myers, 1996). The observation of channels in reflectors $\mathrm{K}-\mathrm{T}, \mathrm{O}$, and $\mathrm{M}$ points towards increased erosion by slope canyons. Drainage coupled with erosion during those periods. Our data reveal that the Cenozoic sedimentary column reaches a maximum thickness of $1400 \mathrm{~m}$ at the continental margin. This appears to be a characteristic value for the whole southern continental margin of South Africa. Broad et al. (2006) report a thickness of only 
G. Uenzelmann-Neben, K. Huhn / Marine Geology 266 (2009) 65-79
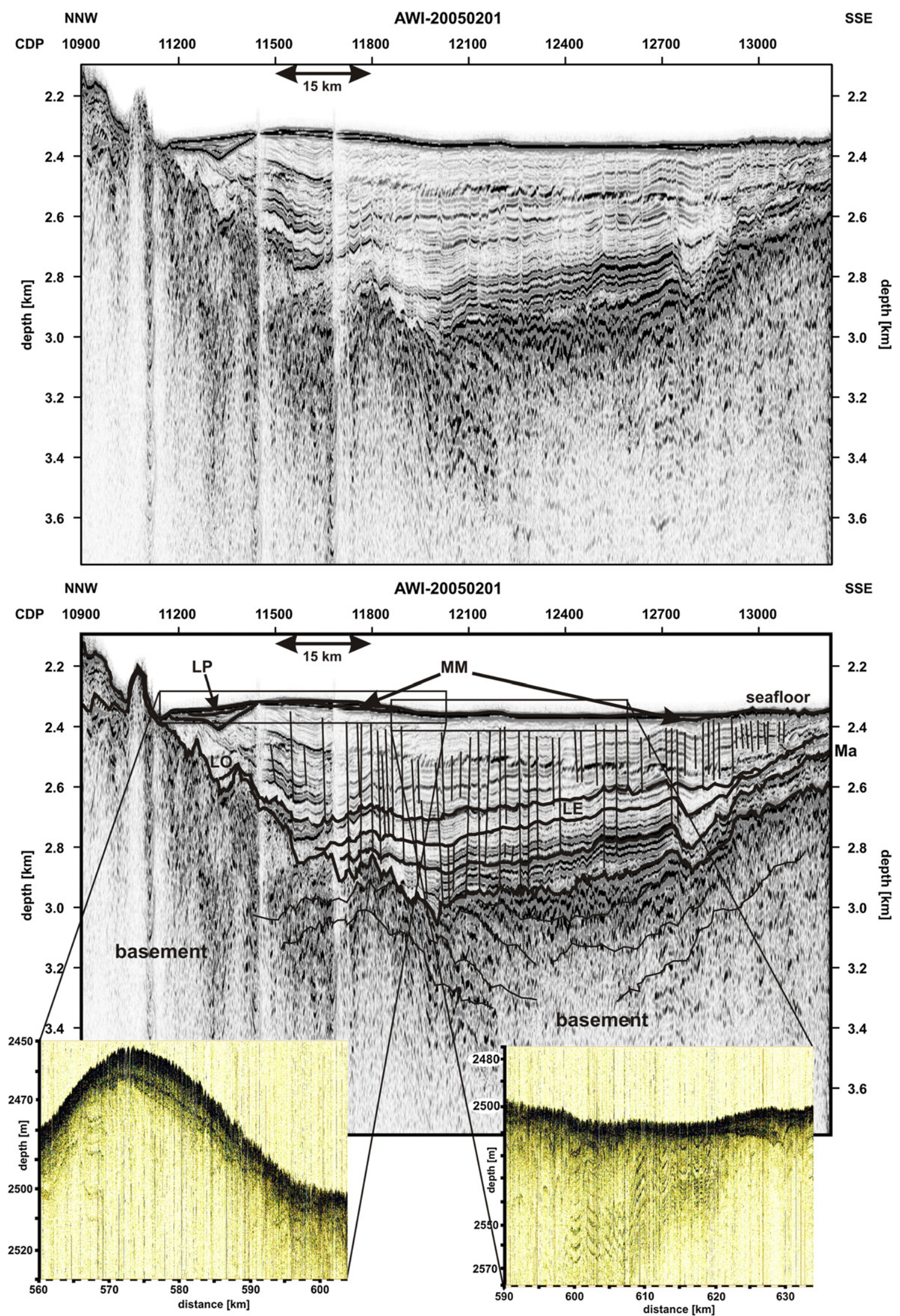

Fig. 9. Seismic profile AWI-20050201 across the southern central Agulhas Plateau (for location see Fig. 1). Note the different scale in the displayed sediment echosounder data (blown-up parts). LE = Paleocene/Eocene boundary, LO = Early/Middle Oligocene, LP= Late Miocene/Early Pliocene, Ma = Maastrichtian, MM = Middle Miocene. 
500-1000 $\mathrm{m}$ for the Cenozoic sediments. This corresponds to a mean sedimentation rate of only $2 \mathrm{~cm} / \mathrm{ka}$. While this may appear as a reasonable rate for the deep sea (e.g. $1 \mathrm{~cm} / \mathrm{ka}$, see Reading, 1996), much higher rates have been reported for both continental slope and rise worldwide (e.g., $>23 \mathrm{~cm} / \mathrm{ka}$ during the past $90 \mathrm{ka}$ at ODP Leg 175 Site $1079,1.6-10 \mathrm{~cm} / \mathrm{ka}$ during the past $1.1 \mathrm{Ma}$ at ODP Leg 175 Site $1080,7-21 \mathrm{~cm} / \mathrm{ka}$ during the past $6 \mathrm{Ma}$ at ODP Leg 175 Site 1082, all on the West African continental margin, Shipboard Scientific Party, 1998b,c,d), 15-19 cm/ka on the Ebro continental margin, Nelson, 1990 ) as well as for numerous shelf areas (e.g. $>24 \mathrm{~cm} / \mathrm{ky}$ during the past 90 ka at ODP Leg 175 Site 1078, Shipboard Scientific Party, 1998a; $\sim 100 \mathrm{~cm} / \mathrm{ka}$ in the Gulf of Mexico, Morse et al., 2002; 170-680 cm/ka on the East China Sea continental shelf, Lin et al., 2000; 9-82 cm/ka on the Ebro continental shelf, Nelson, 1990). Hence, the observed sedimentation rate of $2 \mathrm{~cm} / \mathrm{ka}$ at the southern South African continental margin is very small. Tinker et al. (2008) report even smaller values of only $0.5 \mathrm{~cm} / \mathrm{ka}$ for the Cenozoic, while they observe a mean denudation rate of South Africa of $1 \mathrm{~cm} / \mathrm{ka}$, double the offshore sedimentation rate. Dingle et al. (1987) reported that about $18 \%$ $\left(31^{*} 10^{6} \mathrm{~m}^{3} / \mathrm{a}\right)$ of the modern terrigenous material is supplied to the southern margin of South Africa, which drains the southern Cape province (see Fig. 4 of Dingle et al., 1987). The largest part of South Africa (Orange, Olifants and Berg Rivers) is drained to the west coast with only $4 \%\left(7 * 10^{6} \mathrm{~m}^{3} / \mathrm{a}\right)$ of run-off. $78 \%\left(133 * 10^{6} \mathrm{~m}^{3} / \mathrm{a}\right)$ of the terrigenous material is input at the eastern coast (including the Limpopo and Tugela Rivers) but does not reside there. In fact, the material is transported towards the southwest by the Agulhas Current or by mass movements into the deep sea. Furthermore, Pleistocene sediments on most of the Agulhas Bank have been reported to consist of relict quartz and benthic carbonate sands (Dingle et al., 1987), i.e. rather large grain sizes. Additionally, Martin and Flemming (1986) show that the Holocene unit reaches a thickness of 20-50 m only in the inner shelf wedge of the Agulhas Bank.

So, we not only observe a thin Cenozoic sedimentary column leading to small sedimentation rates but we also observe areas of strong erosion into Oligocene and Cretaceous sediments and even down to basement (Figs. 2-9). Mapping out the locations of those erosional patches a distribution pattern emerges (Fig. 10). At the continental slope and rise, the erosional areas are confined to specific intervals of water depths of 900-1700 m, 2000-2600 m, 2600$3000 \mathrm{~m}$, and $3200-4800 \mathrm{~m}$ (Fig. 10). With $15-30 \mathrm{~km}$ in width, the erosional areas are quite restricted. Similar erosional areas in water depths of 750-1200 $\mathrm{m}$ and $2200-3000 \mathrm{~m}$ can be observed in the data presented by Dingle (1977) as well, where they are attributed to slump activity. Mass movements such as slumps may be discussed as the origin of those erosional areas. A high sediment input as proposed by Dingle et al. (1987), Martin and Flemming (1986), and Tinker et al. (2008) would certainly result in a possibly unstable deposition, which, when reaching a critical thickness and/or inclination of the slope, would be transported into the deep sea. A slump is characterized by a number of features. The head area of a slump is dominated by extensional structures in the form of normal, commonly listric faults (Reading, 1996). In contrast, the downslope part of the slump is dominated by compressional structures such as fold and thrusts. Internal reflectors are continuous and undeformed for short distances with deformation at the toe and along the base (Emery and Myers, 1996). The failure plane at the head is concave-up and subparallel to the adjacent bedding at the toe. The surface usually is hummocky.

Several slumps have been reported for the eastern shelf area of South Africa with the Agulhas Slump being the most prominent and extensive one (Dingle, 1977; Martin and Flemming, 1986; Dingle et al., 1987). The erosional areas observed in our data are found in flat areas. The seafloor there shows dips of $0.5-2.5^{\circ}$ increasing to $8^{\circ}$ at the AFFZ (Figs. 2 and 5). Gradients of $1-1.5^{\circ}$ were observed for the slope in the Cape Basin, where a series of slump scarps provide evidence of mass movements for the period 18-2 Ma (Weigelt and Uenzelmann-Neben, 2004). There, mass movement has been correlated with increased productivity as a result of the Benguela Upwelling. The Cape Basin slump scarps have been filled with younger sediments (Weigelt and Uenzelmann-Neben, 2004). This is not the case on the southern South African continental shelf and slope. Here, the erosional patches are not buried, but appear to be active, as can be seen in the thin cover of soft material resolved by the sediment echosounding data (Figs. 2-7). Furthermore, Dingle et al. (1987) and Meadows et al. (2002) reported that the Pleistocene sediments consist of relict quartz and benthic carbonate sands, which points to extensive winnowing.

In his description Dingle (1977) divided the Agulhas Slumps into a proximal and a distal part. The proximal part is located between $21^{\circ}$

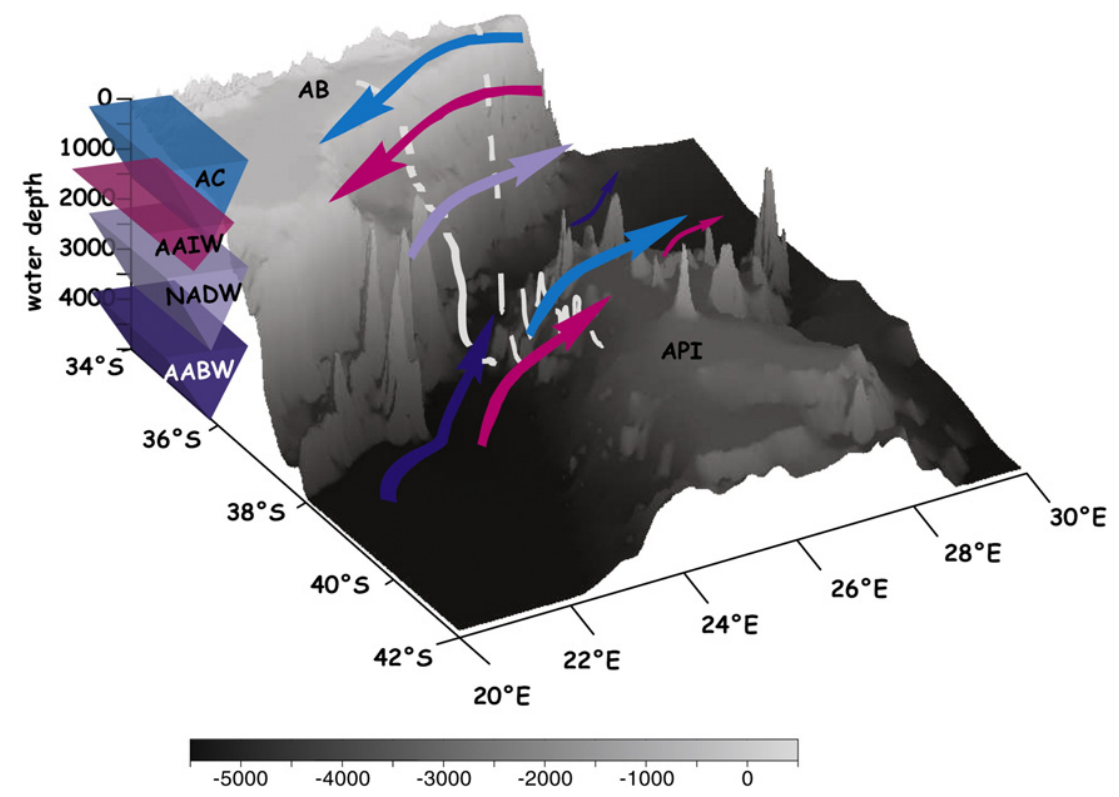

Fig. 10. 3d display of the bathymetry of the southern South African continental margin (Sandwell and Smith, 1997). The black lines show the locations of the seismic profiles, the arrows show the paths of the different water masses Agulhas Current AC (light blue), Antarctic Intermediate Water AAIW (purple), North Atlantic Deep Water NADW (grey), and Antarctic Bottom Water AABW (dark blue). $\mathrm{AB}=$ Agulhas Bank, $\mathrm{APl}=$ Agulhas Plateau. 
$30^{\prime} \mathrm{E}$ and $27^{\circ} 30^{\prime} \mathrm{E}$ in water depths of 190-700 m. Dingle (1977) here observes a fissured zone and a main slump body immediately seaward of the shelf break in water depths of $300-500 \mathrm{~m}$. His data show a prominent glide plane and small topographic depressions in the proximal zone. Both our seismic lines cross Dingle's (1977) proximal slump zone (Fig. 1) but we do not see any evidence for a fissured zone. We observe prograding sedimentary units, which show channels in the Miocene and Oligocene strata (Figs. 2, CDPs 100-700, and 6, CDPs 500-2800). The post-Pliocene unit further shows a strong thinning towards the shelf break (Fig. 5, CDPs 2100-2700) as well as erosion at the seafloor (Fig. 5, CDP 2250). However, a glide plane is not apparent in our data.

Line AWI-20050201 shows a depression between CDPs 600 and 980 (Fig. 2), which is $200-400 \mathrm{~m}$ deep. Seaward, this depression is bound by an anticline in post-Miocene sediments. This depression can be correlated with the St. Francis depression of Dingle (1977). According to his observations, subsidiary faulting within the proximal slump mass formed the depression. Again, our data show neither a glide plane nor faulting. We observe a sediment body, which appears to have been affected by cutting of channels (Fig. 2, CDPs 700-950).

Furthermore, the distal part of Dingle's slump is located on the continental slope and in the west it is confined by the DMR (Dingle, 1977). Our data show erosional patches here on the upper continental slope (Figs. 2, CDPs 1050-1200, and 5, CDPs 2600-2900). Those features may be interpreted as the main glide plane scar although they are observed in water depths of $\sim 900-1600 \mathrm{~m}$ and not in shallower water depths (190-700 m) as reported by Dingle (1977). Seaward of those features we observe lenticular sediment bodies (Fig. 2, CDPs 1200-1700, and 5, CDPs 2900-3800). The sediment lens on the eastern profile is characterized by a prominent base (reflector $\mathrm{M}$ ) and a wedge-out of internal reflectors towards this surface in the head zone (Fig. 2, CDPs 1200-1700). Internal reflections are strong and continuous and merge towards the toe zone. In the lower central part, the sedimentary body shows disrupted bedding. We could therefore interpret this sedimentary lens as part of the Agulhas Slump.

The sedimentary body on the western profile also shows a prominent base (reflector M) (Fig. 5, CDPs 2900-3800). Although the internal reflections are much weaker compared to the sediment body on line AWI-20050201 (Fig. 2) they do not wedge-out towards the base but instead are slightly concave and hence follow the regional trend in bedding (Fig. 5). We are thus reluctant to interpret this sedimentary structure as part of the Agulhas Slump as well.

Although we cannot identify features diagnostic for the Agulhas Slump in the proximal zone (shelf, shelf break) as put forward by Dingle (1977), we have observed structures that may be interpreted as the main glide plane scar, the glide plane and part of the slump body (the later only on the eastern line AWI-20050201) on the upper continental slope. It is important to point out that the scarp, etc. have not been filled or levelled by sediments, which indicates (a) a very recent slumping event, (b) very little sediment input, and/or (c) strong erosion. Dingle (1977) suggested a post-Pliocene age for the Agulhas Slump. This would account for only a thin sediment drape over the slump morphology. We observe a maximum of $50 \mathrm{~m}$, which, using the derived sedimentation rates of $2 \mathrm{~cm} / \mathrm{ka}$ for the South African margin, leads to an age of only $2500 \mathrm{y}$. As already pointed out, about a fifth $(18 \%)$ of the South African terrigenous material is input via the southern coast (Dingle et al., 1987), which, if deposited undisturbed, should result in thick sedimentary units. We do not observe those units. This indicates mass movement, which we only observe on parts of line AWI-20050201 and not as extensively as proposed by Dingle (1977). Therefore, we suggest ongoing erosion as an additional process shaping the sedimentary deposits on the Agulhas Bank.

Water masses with specific physical and chemical properties such as NADW and AABW have been identified as the origin of erosion in a number of places (e.g. Camden-Smith and Dingle, 1981, Dingle, 1980, Tucholke and Embley, 1984, Uenzelmann-Neben et al., 2007, and many others). There, erosional patches bear traces of the currents' paths and intensities. The Agulhas Current (AC) is a powerful geostrophic current with a mean volume flux of $100 \mathrm{~Sv}\left(10^{6} \mathrm{~m}^{3} / \mathrm{s}\right)$ and speeds as high as 1.5-2 m/s (Lutjeharms, 1996; De Ruijter et al., 1999; Lutjeharms, 2006). Thus, the current is strong enough to both prevent deposition of sediment and actively erode silt to sand (grain sizes 10-1000 $\mu \mathrm{m}$ ) (The Open University, 1999). The AC extends to water depths of up to 2000 m (Lutjeharms, 1996; De Ruijter et al., 1999; Lutjeharms, 2006) and here may be responsible for strong non-deposition/erosion on the shelf and upper slope. Flemming (1980) reports a similar erosional activity of the AC for the southeast African shelf.

Another water mass active in water depths of 700-1500 m at the South African continental margin is AAIW (You et al., 2003). AAIW has been considered to be the origin of erosion on the southwest African continental margin as well (Weigelt and Uenzelmann-Neben, 2004). At the southern South African continental margin AAIW flows into the same direction as the AC with a mean flux of $\sim 4$ Sv (You et al., 2003) and probably adds to the non-depositional/erosional activity of the AC. This would account for the uppermost level of erosion observed within our data (900-1700 m water depth).

In water depths of 2000-3500 m NADW flows as a deep western boundary current NE-ward through the Agulhas Passage into the Indian Ocean (Van Aken et al., 2004). The core of NADW lies close to a water depth of $2500 \mathrm{~m}$ south of South Africa. Here, a transport of $\sim 2.8 \mathrm{~Sv}$ at a mean speed of $4 \mathrm{~cm} / \mathrm{s}$ can be observed (Van Aken et al., 2004). The activity depth of NADW correlates well with two further levels of erosion observed in our data: $2000-2600 \mathrm{~m}$ and $2600-$ $3000 \mathrm{~m}$. Weigelt and Uenzelmann-Neben (2004) found evidence for the erosional potential of NADW at the continental slope of southwestern Africa. We thus also interpret NADW as the origin of the nondeposition/erosion in water depths between $2000 \mathrm{~m}$ and $3000 \mathrm{~m}$.

The deepest level where erosional patches are observed at the southern South African continental margin is taken up by AABW (Tucholke and Embley, 1984). AABW has been reported to strongly erode at the rim of the Agulhas Plateau and across the southern plateau (Tucholke and Embley, 1984; Uenzelmann-Neben, 2001; Uenzelmann-Neben, 2002; Uenzelmann-Neben et al., 2007) and is thus considered to be an active non-depositional/erosional force observed in our data as well.

The northern Agulhas Plateau in general shows only a thin and patchy sedimentary cover (Fig. 8, CDPs 5200-8100). In a few places the sedimentary layers show a thickness of up to $500 \mathrm{~m}$ (Fig. 9, CDPs $5300-6100$ ), but generally the thickness is between $100 \mathrm{~m}$ and the vertical resolution $(\sim 8 \mathrm{~m})$ of the seismic data (Fig. 8, CDPs 6100-6700, $7400-7800$ ). This is true for the whole northern plateau irrespectively of the water depth and seafloor topography. The situation is different on the southern Agulhas Plateau, where the sedimentary units are up to $1800 \mathrm{~m}$ thick (Fig. 9 CDPs 11,200-14,000; Uenzelmann-Neben, 2001, 2002). Obviously, non-deposition/erosion is much stronger on the northern Agulhas Plateau. There, return currents of both the AC and AAIW flow across the plateau (Lutjeharms, 1996; You et al., 2003; Lutjeharms, 2006). With their strength (AC 50-75 Sv) and speeds (AC $1.2 \mathrm{~m} / \mathrm{s}$, AAIW $0.3-0.5 \mathrm{~m} / \mathrm{s}$ ), both water masses are able to erode and keep in suspension sediment particles of grain sizes $40-400 \mu \mathrm{m}$ (The Open University, 1999). The southern Agulhas Plateau is affected by AABW activity in only a few locations where both erosional patches and sediment drifts are observed (Uenzelmann-Neben, 2001, 2002).

We have seen that the erosional patches observed in our seismic data correlate well with present day paths and activity depths of the AC, AAIW, NADW, and AABW. Similar erosional patches are observed in the data presented in Dingle (1977) even though he interprets them differently. On the other hand, we could identify only few features (glide plane scarp, glide plane), which are indicative of slumping and have been suggested as the major sediment movement process by Dingle (1977). Those features could only be observed in the distal zone of the slump as defined by Dingle (1977). We hence consider the 
water masses and currents to be the main origin of the observed nondeposition/erosion. More seismic data is needed to better constrain our interpretation. The fact that we observe-deposition/erosion of recent to Oligocene sediments at the southern South African continental margin may thus point towards a longer duration of the erosional activity and hence a stable location of the currents' paths. A way to verify this hypothesis and learn more about the time frame is numerical simulation of sediment erosion (Huhn and UenzelmannNeben, in prep.).

\section{Conclusions}

Seismic profiles extending from the shelf into the deep sea provide information on sedimentary structures on the southern South African shelf, slope, rise, the Agulhas Passage, and the Agulhas Plateau. The main results and conclusions are:

1. The Cenozoic sedimentary column generally is very thin showing a maximum thickness of $1400 \mathrm{~m}$. This leads to extremely low mean sedimentation rates.

2. Erosion of Oligocene to Holocene sediments, and in places of the complete sedimentary column, was observed in specific water depth intervals. Evidence for mass movements such as the Agulhas Slump can be identified in only a few locations. Non-deposition and erosion hence appear to have been the major processes shaping the sedimentary units.

3. Erosion is inferred to be an on-going process since the erosional features are neither filled nor levelled out.

4. The erosional patches correlate well with the activity levels of water masses active at the southern South African continental margin. The AC, AAIW, NADW, and AABW are hence interpreted to be the origin of the past and ongoing active non-deposition and erosion at this continental margin.

5. The observed erosion makes it difficult to study the Neogene climate variations at the South African continental margin because it is difficult to estimate the duration of the erosional processes. The removal of surficial to Oligocene sedimentary layers suggests that the presently observed circulation have been stable since the Neogene.

\section{Acknowledgements}

We acknowledge with gratitude the cooperation of Captain Lutz Mallon and his crew of the German Research Vessel SONNE, who made it possible to obtain the seismic reflection data. We are grateful for the helpful comments of Dr. J. Compton and an unknown reviewer and the editor Dr. D. Piper. This project was funded by the German Bundesministerium für Bildung und Forschung (BMBF) under contract no. 03G0182A. This is AWI publication no. n-17867 and Inkaba yeAfrica contribution No 31.

\section{References}

Barker, P.F., Thomas, E., 2004. Origin, signature and palaeoclimatic influence of the Antarctic Circumpolar Current. Earth-Sci. Rev. 66, 143-166.

Barrett, D.M., 1977. The Agulhas Plateau off South Africa: a geophysical study. Geol. Soc Amer. Bull. 88, 749-763.

Ben Avraham, Z., Hartnady, C.H.J., Malan, J.A., 1993. Early tectonic extension between the Agulhas Bank and Falkland Plateau due to the rotation of the Lafonia microplate. Earth Planet. Sci. Lett. 117, 43-58.

Ben Avraham, Z., Niemi, T.M., Hartnady, C.J.H., 1994. Mid-Tertiary changes in deep ocean circulation patterns in the Natal Valley and Transkei Basin, Southwest Indian Ocean. Earth Planet Sci. Lett. 121, 639-646.

Ben Avraham, Z., Hartnady, C.H.J., Kitchin, K.A., 1997. Structure and tectonics of the Agulhas-Falkland fracture zone. Tectonophysics 282, 83-98.

Broad, D.S., Jungslager, E.H.A., MacLachlan, I.R., Roux, J., 2006. Offshore Mesozoic Basins. In: M.R. Johnson, C.R. Anhaeusser, R.J. Thomas (Eds.), The Geology of South Africa. Geological Society of South Africa/Council for GeoScience, Pretoria, pp. 553-571.
Camden-Smith, F., Perrins, L.-A., Dingle, R.V., Brundrit, G.B., 1981. A preliminary report on long-term bottom-currents measurements and sediment transport/erosion in the Agulhas Passage, southwest Indian Ocean. Mar. Geol. 39 (81-88).

Compton, J.S., Mulabisana, J., McMillan, I.K., 2002. Origin and age of phosphorite from the Last Glacial Maximum to Holocene transgression succession off the Orange River, South Africa. Mar. Geol. 186.

Compton, J.S., Wigley, R., McMillan, I.K., 2004. Late Cenozoic phosphogenesis on the western shelf of South Africa in the vicinity of the Cape Canyon. Mar. Geol. 206, 19-40.

De Ruijter, W.P.M., Biastoch, A., Drijfhout, S.S., Lutjeharms, J.R.E., Matano, R.P., Pichevin, T., et al., 1999. Indian-Atlantic interocean exchange: dynamics, estimation and impact. J. Geophys. Res. C104, 20885-20910.

Dingle, R.V., 1977. The anatomy of a large submarine slump on a sheared continental margin (SE Africa). J. Geol. Soc. (Lond.) 134, 293-310.

Dingle, R.V., 1980. Large allochthonous sediment masses and their role in the construction of the continental slope and rise off Southwestern Africa. Mar. Geol. 37, 333-354.

Dingle, R.V., Camden-Smith, F., 1979. Acoustic stratigraphy and current-generated bedforms in deep ocean basins off southeastern Africa. Mar. Geol. 33, 239-260.

Dingle, R.V., Hendey, Q.B., 1984. Late Mesozoic and Tertiary sediment supply to the eastern Cape Basin (SE Atlantic) and palaeodrainage systems in southwestern Africa. Mar. Geol. 56, 12-26.

Dingle, R.V., Birch, G.F., Bremner, J.M., De Decker, R.H., Du Plessis, A., Engelbrecht, J.C., et al., 1987. Deep-sea sedimentary environments around southern Africa (south-east Atlantic and South-west Indian Ocean). Ann. S. Afr. Mus. 98, 27.

Diz, P., Hall, I.R., Zahn, R., Molyneux, E.G., 2007. Paleoceanography of the southern Agulhas Plateau during the last $150 \mathrm{ka}$ : inferences from benthic foraminiferal assemblages and multispecies epifaunal carbon isotopes. Paleoceanography 22.

Eagles, G., Livermore, R.A., Morris, P., 2006. Small basins in the Scotia Sea: the Eocene Drake Passage gateway. Earth Planet. Sci. Lett. 242, 343-353.

Emery, D., Myers, K., 1996. Sequence stratigraphy. Blackwell Science Ltd.

Flemming, B.W., 1980. Sand transport and bedform patterns on the continental shelf between Durban and Port Elizabeth (southeast African continental margin). Sediment. Geol. 26 (1-3), 179-205.

Fullerton, L.G., Frey, H.V., Roark, J.H., Thomas, H.H., 1989. Evidence for a remanent contribution in MAGSAT data from the Cretaceous Magnetic Quite Zone in the South Atlantic. Geophys. Res. Lett. 16, 105-1088.

Gohl, K., Uenzelmann-Neben, G., 2001. The crustal role of the Agulhas Plateau, southwest Indian Ocean: evidence from seismic profiling. Geophys. J. Int. 144, 632-646.

Lawver, L.A., Gahagan, L.M., 1998. Opening of Drake Passage and its impact on Cenozoic ocean circulation. In: Crowley, T.J., Burke, K.C. (Eds.), Tectonic boundary conditions for climate reconstruction. Oxford Monographs on Geology and Geophysics, Oxford pp. 212-223.

Lin, S., Huang, K.-M., Chen, S.-K., 2000. Organic carbon deposition and its control on iron sulfide formation of the southern East China Sea continental shelf sediments. Cont Shelf Res. 20, 619-635.

Lutjeharms, J.R.E., 1996. The exchange of water between the South Indian and South Atlantic Oceans. In: Wefer, G., Berger W.H. Siedler G. Webb, D.J. (Eds.), The South Atlantic: Present and past circulation. Springer, Berlin, pp. 125-162.

Lutjeharms, J.R.E., 2006. The Agulhas Current. Springer, Berlin Heidelberg. 330 pp.

Mackensen, A., Ehrmann, W.U., 1992. Middle Eocene through early Oligocene climate history and palaeoceanography in the southern Ocean: stable oxygen and carbon isotopes from ODP on Maud Rise and Kerguelen Plateau. Mar. Geol. 108, 1-27.

Martin, A.K., 2007. Gondwana break-up via double-saloon-door rifting and seafloor spreading in a backarc basin during subduction rollback. Tectonophys. 445 245-272.

Martin, A.K., Flemming, B.W. 1986. The Holocene shelf sediment wedge off the south and east coast of South Africa. In: Knight, RJ. McLean, J.R. (Eds.), Shelf sands and sandstones. Memoir. Canadian Society of Petroleum Geologists, pp. 27-44.

Martin, A.K., Flemming, B.W., 1988. Physiography, structure and geological evolution of the Natal continental shelf. In: Schumann, E. (Ed.), Lecture notes on coastal and estuarine studies off Natal, South Africa. Springer, New York, pp. 11-46.

Martin, A.K., Hartnady, C.H.J., 1986. Plate tectonic development of the southwest Indian Ocean: a revised reconstruction of East Antarctica and Africa. J. Geophys. Res. 91, 4767-4786.

Meadows, M.E., Rogers, J., Lee-Thorp, J.A., Bateman, M.D., Dingle, R.V., 2002. Holocene geochronology of a continental shelf mudbelt off southwestern Africa. The Holocene 12 (1), 59-67.

Molyneux, E.G., Hall, I.R., Zahn, R., Diz, P., 2007. Deep water variability on the southern Agulhas Plateau: interhemispheric links over the past $170 \mathrm{ka}$. Paleoceanography 22.

Morse, J.W., Gledhill, D.K., Sell, K.S., Arvidson, R.S., 2002. Pyritization of iron in sediments from the continental slope of the northern Gulf of Mexico. Aquat Geochem. 8, 3-13.

Nelson, C.H., 1990. Estimated post-Messinian sediment supply and sedimentation rate on the Ebro continental margin, Spain. Mar. Geol. 95, 395-418.

Niemi, T.M., Ben Avraham, Z., Hartnady, C.H.J., Reznikov, M., 2000. Post-Eocene seismic stratigraphy of the deep ocean basin adjacent to the southeast African continental margin: a record of geostrophic bottom current systems. Mar. Geol. 162, 237-258.

Parsiegla, N., Gohl, K., Uenzelmann-Neben, G., 2007. Deep crustal structure of the sheared South African continental margin: first results of the Agulhas-Karoo Geoscience Transect. S. Afr. J. Geol. 110.

Parsiegla, N., Gohl, K., Uenzelmann-Neben, G., 2008. The Agulhas Plateau: structure and evolution of a Large Igneous Province. Geophys. J. Int. 174, 336-350.

Rau, A.J., Rogers, J., Lutjeharms, J.R.E., Giraudeau, J., Lee-Thorpe, J.A., Chen, M.-T., et al., 2002. A 450-kyr record of hyrdological conditions on the western Agulhas Bank Slope, south of Africa. Mar. Geol. 180, 183-201. 
Rau, A.J., Rogers, J., Chen, M.-T., 2006. Late Quaternary palaeoceanographic record in giant piston cores off South Africa, possibly including evidence of neotectonism. Quat. Int. 148, 65-77.

Read, J.F., Pollard, R.T., 1999. Deep inflow into the Mozambique Basin. J. Geophys. Res. c104, 3075-3090.

Reading, H.G., 1996. Sedimentary environments: Processes, facies and stratigraphy. Blackwell Science, Oxford. 688 pp.

Sandwell, D.T., Smith, W.H.F., 1997. Global seafloor topography from satellite altimetry and ship depth soundings. Science 277, 1956-1962.

Scher, H.D., Martin, E.E., 2008. Oligocene deep water export from the North Atlantic and the development of the Antarctic Circumpolar Current examined with neodymium isotopes. Paleoceanography 23.

Schlüter, P., Uenzelmann-Neben, G., 2007. Seismostratigraphic analysis of the Transkei Basin: a history of deep sea controlled sedimentation. Mar. Geol. 240, 99-111.

Schlüter, P., Uenzelmann-Neben, G., 2008. Indications for bottom current activity since Eocene times: the climate and ocean gateway archive of the Transkei Basin, South Africa. Glob. Planet. Change 60 (3-4), 416-428.

Shipboard Scientific Party, 1998a. Site 1078. In: Wefer, G., Berger, W.H., Richter, C., et al. (Eds.), Proceedings ODP - Initial Reports. Ocean Drilling Project, College Station, pp. 154-176.

Shipboard Scientific Party, 1998b. Site 1079. In: Wefer, G., Berger, W.H., Richter, C., et al. (Eds.), Proceedings ODP - Initial Reports. Ocean Drilling Project, College Station, pp. 177-199.

Shipboard Scientific Party, 1998c. Site 1080. In: Wefer, G., Berger, W.H., Richter, C., et al (Eds.), Proceedings ODP - Initial Reports. Ocean Drilling Project, College Station, pp. 201-221.

Shipboard Scientific Party, 1998d. Site 1082. In: Wefer, G., Berger, W.H., Richter, C., et al. (Eds.), Proceedings ODP - Initial Reports. Ocean Drilling Project, College Station, pp. 273-312.

The Open University, 1999. Waves, tides and shallow-water processes. Butterworth Heinemann, Oxford. 227 pp.

Tinker, J., De Wit, M., Brown, R., 2008. Linking source and sink: evaluating the balance between onshore erosion and offshore sediment accumulation since Gondwana break-up, South Africa. Tectonophysics 455, 94-103.
Tucholke, B.E., Carpenter, G.B.,1977. Sedimentary distribution and Cenozoic sedimentation patterns on the Agulhas Plateau. Geol. Soc. Amer. Bull. 88, 1337-1346.

Tucholke, B.E., Embley, R.E., 1984. Cenozoic regional erosion of the abyssal sea floor off South Africa. In: Schlee, J.S. (Ed.), Interregional unconformities and hydrocarbon accumulation. Memoir. American Association of Petroleum Geologists, pp. 145-164.

Uenzelmann-Neben, G., 2001. Seismic characteristics of sediment drifts: an example from the Agulhas Plateau, southwest Indian Ocean. Mar. Geophys. Res. 22, 323-343.

Uenzelmann-Neben, G., 2002. Contourites on the Agulhas Plateau, SW Indian Ocean: indications for the evolution of currents since Paleogene times. In: Stow, D.A.V., Pudsey, C.J., Howe, J.A., Faugeres, J.-C., Viana, A.R. (Eds.), Deep-water contourite systems: Modern drifts and ancient series, seismic and sedimentary characteristics. Geological Society London, pp. 271-288.

Uenzelmann-Neben, G., Gohl, K., Ehrhardt, A., Seargent, M., 1999. Agulhas Plateau, SW Indian Ocean: new evidence for extensive volcanism. Geophys. Res. Lett. 26, 1941-1944.

Uenzelmann-Neben, G., Schlüter, P., Weigelt, E., 2007. Cenozoic oceanic circulation within the South African gateway: indications from seismic stratigraphy. S. Afr. J. Geol. 110, 275-294.

Van Aken, H.M., Ridderinkhoff, H., De Ruijter, W.P.M., 2004. North Atlantic deep water in the south-western Indian Ocean. Deep-Sea Res. I 51, 755-776.

Weigelt, E., Uenzelmann-Neben, G., 2004. Sediment deposits in the Cape Basin: indications for shifting ocean currents? AAPG Bull. 88, 765-780.

Winter, A., Martin, A.K., 1990. Late Quaternary history of the Agulhas Current. Paleoceanography 5, 479-486.

Yilmaz, Ö., 2001. Seismic Data Analysis. In: Investigations in Geophysics, vol. 10. Society of Exploration Geophysicists, Tulsa. 2027 pp.

You, Y., Lutjeharms, J.R.E., Boebel, O., De Ruijter, W.P.M., 2003. Quantification of the interocean exchange of intermediate water masses around southern Africa. DeepSea Res. II 50, 197-228.

Zachos, J., Pagani, M., Sloan, L.C., Thomas, E., Billups, K., 2001. Trends, rhythms and aberations in global climate 65 Ma to present. Science 292, 686-693. 